\title{
REFRAMING KURTZ'S PAINTING: COLONIAL LEGACIES AND MINORITY RIGHTS IN ETHNICALLY DIVIDED SOCIETIES
}

\author{
TOM BROWER*
}

\begin{abstract}
Minority rights constitute some of the most normatively and economically important human rights. Although the political science and legal literatures have proffered a number of constitutional and institutional design solutions to address the protection of minority rights, these solutions are characterized by a noticeable neglect of, and lack of sensitivity to, historical processes. This Article addresses that gap in the literature by developing a causal argument that explains diverging practices of minority rights protections as functions of colonial governments' variegated institutional practices with respect to particular ethnic groups. Specifically, this Article argues that in instances where colonial governments politicize and institutionalize ethnic hegemony in the pre-independence period, an institutional legacy is created that leads to lower levels of minority rights protections. Conversely, a uniform treatment and depoliticization of ethnicity prior to independence ultimately minimizes ethnic cleavages postindependence and consequently causes higher levels of minority rights protections. Through a highly structured comparative historical analysis of Botswana and Ghana, this Article builds on a new and exciting research agenda that focuses on the role of long-term historio-structural and institutional influences on human rights performance and makes important empirical contributions by eschewing traditional methodologies that focus on single case studies that are largely descriptive in their analyses. Ultimately, this Article highlights both the strength of a historical approach to understanding current variations in minority rights protections and the varied institutional responses within a specific colonial government.

\footnotetext{
Copyright (C) 2016 Tom Brower

* Vinson \& Elkins LLP; J.D. 2015, University of Virginia School of Law; M.A. 2012, Indiana University; B.A. 2008, Washington and Lee University. This Article was presented at the Fifth Annual Global Conference of the Younger Comparativists Committee of the American Society of Comparative Law on March 18-19, 2016. I am very grateful to Mila Versteeg for her guidance and constructive comments on this Article and the staff of the Duke Journal of Comparative \& International Law for their
} excellent editorial work.
\end{abstract}




\section{TABLE OF CONTENTS}

I. INTRODUCTION 36

II. MINORITY RIGHTS AS INTERNAL SELF-DETERMINATION …..............39

A. Democracy and its Discontents ............................................................ 40

1. Consociational Democracy and Proportional Representation ........ 41

2. Integrationist Democracy and Alternative Vote............................. 43

B. When the Center Holds: Autonomy Regimes........................................ 44

C. Polyethnic Rights and Cultural Protections ............................................ 47

III. A PATH DEPENDENT THEORY OF COLONIAL LEGACIES AND

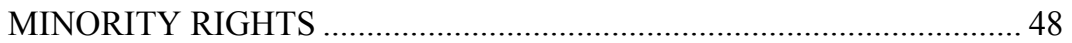

A. Historical Institutionalism and Path Dependency …………………..... 48

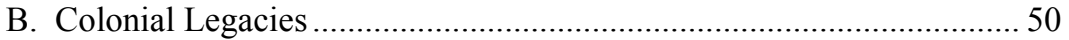

1. Constructing Bula Matari? ………………………………............. 50

2. Colonialism and the Imagining of Ethnicity .................................. 52

C. Linking Colonial Legacies and Minority Rights …………………....... 54

IV. DIVERGING PATHS OF MINORITY RIGHTS IN BOTSWANA AND

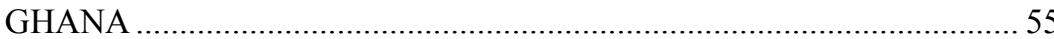

A. Research Design.............................................................................. 55

B. Botswana: Imagined and Instrumentalized Ethnic Homogeneity..........56

1. Pre-Independence: Tswana as Intermediary .................................... 56

2. Post-Independence: Tswana as Hegemon ....................................... 58

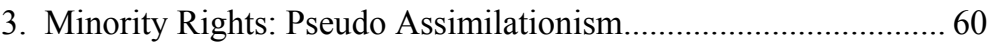

C. Ghana: Depoliticized yet Conscious Ethnicity ………………………......64 64

1. Pre-Independence: The Mismatch of Ethnicity and Tribe.............. 64

2. Post-Independence: Politicized Ethnicity as Anathema ………...... 66

3. Minority Rights: Successful Integrationism................................... 68

V. REFRAMING HISTORY? MINORITY RIGHTS LOOKING FORWARD .. 70

"I rose. Then noticed a small sketch of oils, on a panel, representing a woman, draped and blind-folded, carrying a lighted torch. The background was sombre-almost black. The movement of the woman was stately, and the effect of the torchlight on the face was sinister."

-Joseph Conrad, Heart of Darkness

\section{INTRODUCTION}

Minority rights constitute some of the most normatively and economically important human rights. ${ }^{1}$ Though indigenous groups

1. See Will Kymlicka, Politics in the Vernacular: Nationalism, Multiculturalism, AND CITIZENSHIP 6 (2001) (describing a "clear shift in public opinion" in viewing minority rights as a matter of "fundamental justice"); Ilan Saban, Minority Rights in Deeply Divided Societies: A Framework for Analysis and the Case of the Arab-Palestinian Minority in Israel, 36 N.Y.U. J. INT’L L. \& POL. 885, 
traditionally constitute national minorities, they face particular harships, ${ }^{2}$ and, accordingly, are generally afforded robust legal protections under international law. ${ }^{3}$ Notwithstanding these exigencies, minority rights constitute some of the most difficult human rights to protect and enforce. ${ }^{4}$ Although the political science and legal literatures have proffered a number of constitutional and institutional design solutions to address the protection of minority rights, these solutions are characterized by a noticeable neglect of, and lack of sensitivity to, historical processes. This Article addresses that gap in the literature by developing a causal argument that explains diverging practices of minority rights protections as functions of colonial governments' variegated institutional practices with respect to particular ethnic groups. ${ }^{5}$

Although contemporary approaches to minority rights protections vary widely with respect to their conceptualization of ethnicity and how institutions should be designed to address the question of minority rights, ${ }^{6}$ this Article emphasizes the causal effects of historically-conditioned institutions on current protections of minority rights. Specifically, this Article draws on principles of historical institutionalism and colonial legacy to argue that variations in how ethnicity was conceptualized and institutionalized during colonial rule created particular post-colonial institutions that shaped current minority rights protections. Specifically, when ethnicity is institutionalized and politicized during colonial rule, lower levels of minority rights are expected in the future, not only because ethnicity is a salient political cleavage, but also because ethnic groups are often placed into asymmetrical political power relationships. Thus, in these instances,

907 (2004) (explaining that "group-differentiated rights" provide "significant" and "permanent" protection to minority groups); Yousef T. Jabareen, Redefining Minority Rights: Successes and Shortcomings of the U.N. Declaration on the Rights of Indigenous Peoples, 18 U.C. DAVIS J. INT'L L. \& POL'Y 119, 140-41 (2011) (explaining that "international discourse has reached a consensus that minority groups require special legal protections of its status" to resist pressures from the majority).

2. See Abdulrahim P. Vijapur, International Protection of Minority Rights, 43 INT'L STUD. 367, 387 (2006); Siegfried Wiessner, Rights and Status of Indigenous Peoples: A Global Comparative and International Legal Analysis, 12 HARV. HuM. RTS. J. 57, 98 (1999); Carolyn Stephens et al., Indigenous Peoples' Health-Why Are They Behind Everyone, Everywhere?, 366 THE LANCET 10, 11 (2005).

3. See StÉPhanie C. JANEt, Minority Rights Group International, Development, Minorities And Indigenous Peoples: A Case Study and Evaluation of Good Practice 10 (2002); Jabareen, supra note 1, at 130-31.

4. See Elena A. Baylis, Minority Rights, Minority Wrongs, 10 UCLA J. INT'L L. \& ForeIGN AfF. $66,66,73$ (2005).

5. See Carola Lentz \& Paul Nugent, Ethnicity in Ghana: A Comparative Perspective, in ETHNiCiTy IN GHANA: The Limits of InVEnTion 6 (Carola Lentz \& Paul Nugent eds., 2000) ("Ethnicity is indeed above all a problem that has to be approached historically, but through history of a particular kind, namely an approach that breaks through the epistemological barrier between the pre-colonial, colonial and post-colonial periods.").

6. See infra notes 9-14 and accompanying text. 
ethnic majorities in power will likely have less respect for minority rights. Conversely, when ethnicity is depoliticized during colonial periods, higher protections of minority rights can be expected because ethnicity has not emerged as a salient political cleavage and no ethnic group has a historically privileged position of political power compared to other ethnic groups. This Article makes substantial and important contributions to the human rights literature. On conceptual and theoretical fronts, this Article builds on new and exciting research by Adam Chilton and Eric Posner that focuses on the role of long-term historio-structural and institutional influences on human rights performance. ${ }^{7}$ By utilizing the concepts of critical junctures and pathdependency, this Article furthers this research agenda by introducing new conceptual and theoretical tools into the human rights law toolkit. Empirically, this Article makes important contributions by eschewing traditional methodologies that focus on single case studies that are largely descriptive in their analyses. ${ }^{8}$ Instead, it provides a highly-structured, comparative historical analysis of two most similar cases. In doing so, this Article highlights both the strength of a historical approach to understanding current variations in minority rights protections and the varied institutional responses within a specific colonial government.

This Article is organized as follows. Section II reviews the literature on minority rights through the conceptual lens of internal self-determination and the constitutional and institutional design principles that have been advanced to support the protection of minority rights. Section III develops a theoretical framework that blends principles of historical institutionalism and path dependency with the colonial state's role of transforming and institutionalizing ethnicity. It then draws a causal connection between this theory and current variations in minority rights protections. Section IV qualitatively and quantitatively compares two former British African colonies with differing degrees of minority rights protections - Botswana and Ghana - in order to provide empirical support for a historical theory of minority rights protections. Section V concludes, offers policy recommendations and identifies implications for future scholarship.

7. See Adam S. Chilton \& Eric A. Posner, The Influence of History on States' Compliance with Human Rights Obligations 4-6 (U. Chi. Pub. Law \& Legal Theory Working Paper No. 513, 2015), http://chicagounbound.uchicago.edu/public_law_and_legal_theory/531/[https://perma.cc/ZB6J-ZP2Y] (56 VA. J. INT'L L. forthcoming 2016).

8. See, e.g., Jeremy Sarkin \& Amelia Cook, The Human Rights of the San (Bushmen) of Botswana - the Clash of the Rights of Indigenous Communities and Their Access to Water with the Rights of the State to Environmental Conservation and Mineral Resource Exploitation, 20 J. TRANSNAT'L L. \& POL'Y 1 (2011); Nicholas Olmsted, Indigenous Rights in Botswana: Development, Democracy and Dispossession, 3 WASH. U. Global StUd. L. REV. 799 (2004). 


\section{MINORITY RIGHTS AS INTERNAL SELF-DETERMINATION}

The question of how to design formal political institutions to best protect minority rights speaks to a broader theoretical question of integration versus accommodation. ${ }^{9}$ Accommodationists "insist that in certain context[s], national, ethnic, religious and linguistic divisions and identities are resilient, durable and hard." ${ }^{10}$ As a result, accommodation supports "dual or multiple identities" and "minimally requires the recognition of one or more ethnic, linguistic, national or religious community in the state. ${ }^{" 11}$ By comparison, integrationists reject the idea that ethnic differences should translate into differences in the political area. ${ }^{12}$ Instead, they advocate for a common public identity despite ethnocultural or ethnolinguistic diversity. ${ }^{13}$ From an institutional perspective, integrationists may advocate for ethnocultural assimilation, which renders impossible political mobilization around ethnic differences, or more mediated institutional strategies that promote a public identity without imposing ethnocultural uniformity in private and associational life. ${ }^{14}$

The international human rights framework has grounded minority rights within the right of self-determination. According to Patrick Thornberry, "[ $t]$ he external dimension or aspect defines the status of a people in relation to another people, State or Empire, whereas the democratic or internal dimension should concern the relationship between a people and 'its own' State or government." ${ }^{15}$ Specifically, the right to self-determination operates solely within the territorial boundaries of existing states through domestic political institutions. ${ }^{16}$ Although operationalizing the right to self-

9. See generally John McGarry et al., Integration or Accommodation? The Enduring Debate in Conflict Regulation, in CONSTITUTIONAL DESIGN FOR DIVIDED SOCIETIES: INTEGRATION OR Accommodation? 41-88 (Sujit Choudhry ed., 2008); John Boye Ejobowah, Integrationist and Accommodationist Measures in Nigeria's Constitutional Engineering: Successes and Failures, in CONSTITUTIONAL DESIGN FOR Divided SOCIETIEs: INTEGRATION OR ACCOMMODATION?, supra note 9, at $233-57$.

10. Sujit Choudhry, Bridging Comparative Politics and Comparative Constitutional Law: Constitutional Design in Divided Societies, in CONSTITUTIONAL DESIGN FOR Divided Societies: INTEGRATION OR ACCOMMODATION?, supra note 9, at 27.

11. Id.

12. Id.

13. Id

14. Id.

15. Patrick Thornberry, The Democratic or Internal Aspect of Self-Determination with Some Remarks on Federalism, in MODERN LAW OF SELF-DETERMINATION 101, 101 (Christian Tomuschat ed., 1993).

16. See Gregory H. Fox, Self-Determination in the Post-Cold War Era: A New Internal Focus?, 16 MICH. J. INT'L L. 733, 734 (1995) (describing the common "strategy" of characterizing minority rights as essentially within the "internal right" of self-determination, and thus a matter of "domestic political institutions"). 
determination as an internal right may require a restructuring of domestic institutions, laws, and policies, changing the physical boundaries of the state and infringing on its territorial integrity would not be required. ${ }^{17}$ The literature has generally focused on three sets of institutions to foster the protection of minority rights: (1) democratic institutions, (2) autonomy regimes, and (3) cultural protections. ${ }^{18}$

Increasingly, human rights scholars have noted that "[t]he very definition of the state must ... reflect the ethnic diversity of the polity, and acknowledge that the state is an aggregation of ethnically and linguistically distinct regions and sometimes of several distinct nationalities." 19 Accordingly, constitutions have been assigned particularly important functions in divided societies. First, constitutions perform a regulatory role and influence political decision-making by creating the "rules of the game.", However, Sujit Choudhry notes that "a constitution must go further and constitute the very demos which governs itself under and through the constitutional regime." 21 Indeed, constitutions are often considered a principal vehicle for creating common political identities, articulating a particular view of the political community, and securing legitimacy for the exercise of political power. ${ }^{22}$ Due to the shortcomings of majoritarian democracies with respect to the protection of minority rights, ${ }^{23}$ constitutions emerge as a central defining power in divided societies because of their inherent tension with, and constraining power on, democratic majoritarianism. ${ }^{24}$

\section{A. Democracy and Its Discontents}

As a first-order issue, the literature has generally agreed that democracies are better suited to promote and protect minority rights than autocratic, authoritarian, or other hegemonic regimes. ${ }^{25}$ However, the

17. See id.

18. See id. at $734,752-56$.

19. Neelan Tiruchelvam, The Crisis of Constitutionalism: South Asian Perspectives, in CONSTitutionalism AND Democracy: Transitions in THE CONTEMPORARY WORLD 361, 363 (Douglas Greenberg et al. eds., 1993). However, it is worth noting that this international human rights law position exists merely as soft law and lacks authoritative commentary.

20. See Choudhry, supra note 10, at 5-6; see generally STEPHEN HOLMES, PASSIONS AND CONSTRAINT: ON THE THEORY OF LIBERAL DEMOCRACY (1995).

21. Choudhry, supra note 10 , at 5-6. Choudhry describes this as the "constitutive conception."

22. See id. at 6; Samuel Issacharoff, Constitutionalizing Democracy in Fractured Societies, 82 TEX. L. REV. 1861, 1863 (2004).

23. See infra notes $26-30$ and accompanying text.

24. Issacharoff, supra note 22, at 1861.

25. Compare Donald RothChild, MANAging Ethnic CONFLict IN Africa 18 (1997) (“[i]n sum, hegemonic regimes failed to enclose social conflict and tended to foster deadlocks in state-society 
particular institutional design is of utmost importance, given the acrimonious stance the literature has taken towards majoritarian democracy in communally and ethnically divided societies. As Donald Horowitz notes, "[i]n ethnically divided societies, majority rule is not a solution; it is a problem, because it permits domination, apparently in perpetuity." ${ }^{26}$ The dominant political actor in divided societies is the ethnic political party, with individuals casting votes on purely ethnic lines. Accordingly, elections become censuses. ${ }^{27}$ The indefinite exclusion of minority groups from politics has important functional and normative implications. According to Adam Przeworski, the stability of electoral democracy rests on the losers accepting defeat in expectation that they might be able to win in subsequent elections. ${ }^{28}$ However, this is not a realistic expectation when majoritarian democracy is utilized in severely fractured societies. Furthermore, Arend Lijphart notes that the most important requirement of democracy is that citizens have the opportunity to participate in decision making, either directly or indirectly. ${ }^{29}$ Accordingly, narrow majority rule is "totally immoral, inconsistent with the primary meaning of democracy, and destructive of any prospect of building a nation in which different peoples might live together in harmony." ${ }^{, 30}$ In light of majoritarian democracy's ill-fit within divided societies, the literature has proffered other democratic institutional designs that better suit the needs of these societies and better protect minority rights.

\section{Consociational Democracy and Proportional Representation}

Consociational democracy has been championed as a democratic model capable of facilitating interethnic and intercommunal accommodation, managing ethnic cleavages, and yielding politically stable democracies. ${ }^{31}$ The critical elements of the consociational model are:

relations."), with id. at 48 ("Democratic regimes, with their emphasis upon low state control, open party contestation, regular elections, and public accountability, provide features that can facilitate intergroup cooperation."). But see Amy L. Chua, Markets, Democracy, and Ethnicity: Toward A New Paradigm for Law and Development, 108 YALE L.J. 1, 5 (1998) ("[I]n the developing world, democracy characteristically pits a politically powerful but impoverished "indigenous" majority against an economically dominant ethnic minority.") (footnote omitted).

26. Donald L. Horowitz, Democracy in Divided Societies, 4 J. DEM. 18, 29 (1993); see also Li-ann Thio, Constitutional Accommodation of the Rights of Ethnic and Religious Minorities in Plural Democracies: Lessons and Cautionary Tales from South-East Asia, 22 PACE INT'L L. REV. 43, 65 (2010).

27. Donald L. Horowitz, Ethnic Conflict Management for Policymakers, in CONFLICT AND Peacemaking in Multiethnic Societies 115, 116 (Joseph V. Montville ed., 1990).

28. AdAm PRZEWORSKi, DEMOCRACY AND THE MARKET: POlitiCAL AND ECONOMIC REFORMS IN EASTERN EUROPE AND LATIN AMERICA 23-24 (1991).

29. Arend Lijphart, Back to Democratic Basics: Who Really Practices Majority Rule?, in DEMOCRACY's VICTORY AND CRISIS 143, 143 (Axel Hadenius ed., 1997).

30. Id. (emphasis omitted).

31. See id.; Arend Lijphart, Constitutional Design for Divided Societies, 15 J. DEM. 96,99 (2004) 
(1) government by a grand coalition of all significant segments; (2) a mutual veto or concurrent-majority voting rule for some or all issues; (3) proportionality as the principle for allocating political representation, public funds, and civil service positions; and (4) considerable autonomy for various segments of the society to govern their internal affairs. ${ }^{32}$

Recently, the model has been simplified to focus on two primary elements: "broad participation in decision making by the representatives of different ethnic-communal groups and cultural autonomy for those groups that wish to have it." 33 The key to the consociational model's power sharing mechanism is the fragmentation of political representation through a proportional representation ("PR") voting system that promotes the representation of minorities who would be outvoted in a single member district plurality scheme under majoritarian democracy. ${ }^{34}$ Fragmented legislatures create incentives for cross-ethnic cooperation in the legislature and in the executive through grand coalition cabinets. ${ }^{35}$ Mutual vetoes and segmental autonomy provide an additional layer of institutional safeguards that create incentives for minority leaders to engage in the political process. ${ }^{36}$ Although the consociational model has been criticized as relatively rigid in its institutional design, Arend Lijphart has noted that each of the institutional requirements can be tailored to specific societal circumstances with respect to both design and implementation. ${ }^{37}$

However, consociational democracy and PR systems have been criticized as being "motivationally inadequate" insofar as they fail to explain why leaders of ethnic groups would have the proper incentives to cooperate and enter into a power sharing arrangement in the first place. ${ }^{38}$ Critiques of these models suggest little incentive for ethnic parties to adopt moderate, cross-cutting policies because these parties ultimately come under attack

(advocating power sharing as a democratic model that "offers the best fit for most divided societies regardless of their individual circumstances and characteristics").

32. Arend Lijphart, Democracy in Plural Societies: A COMParative Exploration 25 (1977).

33. Lijphart, supra note 29, at 143; see also Choudhry, supra note 10, at 18-19.

34. For qualitative support, see DonALD L. HoROwITZ, ETHNIC GROUPS IN CONFLICT $641-45$ (1985) (Sri Lanka and Guyana).

35. Choudhry, supra note 10, at 19; see Issacharoff, supra note 22, at 1864.

36. Choudhry, supra note 10 , at 19.

37. Arend Lijphart, Consociation: The Model and its Applications in Divided Societies, in Political Co-OPERATION IN Divided Societies 166, 174-75 (Desmond Rea ed., 1983).

38. Donald L. Horowitz, Constitutional Design: Proposals Versus Processes, in THE Architecture of Democracy: Constitutional Design, Conflict Management, and DEMOCRACY 20 (Andrew Reynolds ed., 2002); Richard H. Pildes, Ethnic Identity and Democratic Institutions: A Dynamic Perspective, in Constitutional DESIGN For Divided SocieTIES, supra note 9 , at 173, 189-90. 
from extremist parties in an "ethnic outbidding" process. ${ }^{39}$ Accordingly, politics remains a zero-sum game for each ethnic party. Because there are penalties rather than incentives for inter-ethnic cooperation, the short-term stability of a particular inter-ethnic coalition and the long-term stability of the institutional system as a whole are undermined. ${ }^{40}$

\section{Integrationist Democracy and Alternative Vote}

As a response to the extant critiques of consociational democracy and PR systems, Donald Horowitz has proffered an integrationist democratic model and a set of electoral institutions that create political incentives for ethnic moderation. ${ }^{41}$ Accordingly, the analytical focus of integration is on encouraging the crossing of the so-called ethnic aisle rather than a pure power sharing regime. Thus, the underlying logic is to concurrently require ethnic parties to rely on other groups and "make moderation pay" by rewarding ethnic parties that appeal to ethnic groups other than their own. ${ }^{42}$ This focus on moderation seeks to marginalize intra-ethnic competition at the extremes through an electoral tradeoff: the possibility of cross-ethnic support should offset electoral losses from the extremes. However, this cross-ethnic support is conditioned on a moderation of platforms and political conduct. ${ }^{43}$

In the integrationist model, ethnic moderation is accomplished through inter-ethnic vote transfers, also known as "vote pooling."44 The institutional mechanism to facilitate vote pooling is the alternative voting electoral system. Voters rank candidates in order of preference and, if a candidate is not elected through first preferences, the bottom candidate is dropped and the second preferences are distributed. Accordingly, incentives are created to appeal across ethnic lines in order to acquire enough second preferences from other ethnic groups to secure a majority. ${ }^{45}$ As a result, "[t]here is an ex ante effect that might moderate ethnic divides among voters. ${ }^{246}$ Empirically, vote pooling systems have been met with mixed results. ${ }^{47}$

39. Choudhry, supra note 10 , at 21 .

40. See id.; Adeno Addis, Deliberative Democracy in Severely Fractured Societies, 16 IND. J. Global Legal Stud. 59, 67 (2009).

41. Donald L. Horowitz, The Cracked Foundations of the Right to Secede, 14 J. DEM. 5, 15 (2003); see Donald L. Horowitz, Constitutional Design: An Oxymoron?, in Designing Democratic InSTITUTIONS 253, 262 (Ian Shapiro \& Stephen Macedo eds., 2000).

42. Donald L. Horowitz, Making Moderation Pay: The Comparative Politics of Ethnic Conflict Management, in CONFLICT AND PEACEMAKING IN MULTIETHNIC SOCIETIES, supra note 27, at 471.

43. Choudhry, supra note 10, at 21.

44. See id.; Pildes, supra note 38, at 190-91.

45. Choudhry, supra note 10 , at 21.

46. Pildes, supra note 38 , at 191.

47. See Jon Fraenkel \& Bernard Grofman, Does the Alternative Vote Foster Moderation in 
B. When the Center Holds: Autonomy Regimes

Autonomy regimes broadly constitute a package of institutions and policies focusing on principles of federalism and intergovernmental relations. Although institutionally and analytically distinct from voting systems, federalism can be used to complement and reinforce a particular voting model. It is generally agreed that federalism has two essential attributes. First, federalism requires that political power be structurally dispersed among multiple centers of authority. ${ }^{48}$ This dispersion creates a "set of nested, geographically based governmental institutions in which the central authority and each of the subauthorities exercise separate normative control over segments of the political environment."49 Accordingly, subnational units have a right to enjoy part of the autonomy they would have possessed as independent states, while the central government retains general authority over the entire territory. Federalism's second attribute lies in the constitutional mandate guaranteeing the legitimacy of the authority of the various subnational units and their claims of right against the central government. ${ }^{50}$ In a unitary system, decentralized power can be reclaimed at the central government's discretion. By contrast, in a federal system, "subordinate units possess prescribed areas of jurisdiction that cannot be invaded by the central authority, and leaders of the subordinate units draw their power from sources independent of that central authority." ${ }^{51}$ However, it is important to note the decentralization and recentralization must be viewed both as a question of degree as well as a dynamic process. ${ }^{52}$

Federalism is widely considered an effective institutional design principle for accommodating ethnic diversity, fostering embedded values within ethnic communities, and facilitating self-rule. ${ }^{53}$ Indeed, "federalism

Ethnically Divided Societies? The Case of Fiji, 39 COMP. PoL. STUD. 623, 648 (2006); Richard H. Pildes \& Kristin A. Donoghue, Cumulative Voting in the United States, 1995 U. CHI. LEG. F. 241, 243. But see Pildes, supra note 38, at 191.

48. DANIEL J. ElAZAR, EXPLORING FEDERALISM 34 (1987).

49. Kim Lane Scheppele, The Ethics of Federalism, in POWER DIVIDED: EsSAYS ON THE THEORY AND PRACTICE OF FEDERALISM 51, 52 (Harry N. Scheiber \& Malcolm M. Feeley eds., 1989).

50. ELAZAR, supra note 48, at 34.

51. Edward L. Rubin \& Malcolm Feeley, Federalism: Some Notes on a National Neurosis, 41 UCLA L. REV. 903, 911 (1994).

52. See J. TYler DickOVICK, DECENTRALIZATION AND RECENTRALIZATION IN THE DEVElOPING WORLD: COMPARATIVE STUDIES FROM LATIN AMERICA AND AFRICA 2 (2011).

53. See Thio, supra note 26 , at 48 ("In some cases, particularly where ethnic-religious cleavages are territorially based, forms of spatial autonomy such as federalism, confederalism, and confederation may be useful methods to adopt pursuant to the principle of "internal self-determination."'); see also KYMLICKA, supra note 1, at 92; Pildes, supra note 38, at 198; Alemante G. Selassie, Ethnic Federalism: Its Promise and Pitfalls for Africa, 28 YALE J. INT'L L. 51, 57 (2003); HoROwITZ, supra note 34, at 61721. 
is particularly attractive as compared with the more overtly consociational features conventionally, and frequently, used in divided societies." ${ }^{, 5}$ Federalism provides an important layer of protection for ethnic minorities, particularly in nations characterized by de jure non-discrimination but de facto political exclusion due to ethnic hegemony. ${ }^{55}$ The literature has advanced both political and economic arguments to support federalism with respect to the protection of minority rights. Subnational ethnic autonomy has been identified as one form of institutional arrangement that is congruent with ethno-nationalist beliefs focusing on "the distinctiveness of a particular people and their right to self-rule in their homeland." ${ }^{56}$ Diane Orentlicher considers two different views of democracy aimed at legitimizing ethnic federalism. First, the utilitarian view contends that ethnic federalism offers the best domestic institutional framework for aggregating the interests of the members of an ethnic group and for promoting democratic governance. ${ }^{57}$ Second, the republican view focuses on ethnic federalism's potential to create an enabling environment for citizens to consider the common good in their public deliberations. ${ }^{58}$ Synthesizing these two views, framing politics within a federal context provides subnational representatives incentives to work within the established system of government to further the aggregate interests of their ethnic constituency.

Furthermore, federalism may offer a plethora of economic benefits. The literature has recognized that subnational units provide a necessary foundation for fostering economic competition, expanding resources, and enhancing the efficiency of a nation as a whole. ${ }^{59}$ Beyond promoting

54. Pildes, supra note 38 , at 198.

55. See Robert A. Dahl, Political Oppositions in Western Democracies 350-51 (arguing that, in general, constitutional separation of powers tends to encourage cooperative and coalescent strategies; separation of power and federalism "decreases the distinctiveness of the opposition and the chances for a strictly competitive contest between government and opposition"). This is closely related to the issues with majoritarian democracy in divided societies. See supra notes 26-30 and accompanying text.

56. Milton J. Esman, Ethnic Politics 28 (1994); see also Amy L. Chua, The Paradox of Free Market Democracy: Rethinking Development Policy, 41 HARV. INT'L L.J. 287, 315 (2000) (distinguishing ethnonationalism as "that form of nationalism 'in which the nation is defined in terms of assumed blood ties and ethnicity"').

57. Diane F. Orentlicher, Separation Anxiety: International Responses to Ethno-Separatist Claims, 23 YALE J. INT'L L. 1, 53-54 (1998).

58. Id. at $54-56$.

59. Gabriella Montinola et al., Federalism, Chinese Style: The Political Basis for Economic Success in China, 48 WORLD POL. 50, 58 (1995). This argument is more generally known as "marketpreserving federalism." See Barry R. Weingast, The Economic Role of Political Institutions: MarketPreserving Federalism and Economic Development, 11 J.L. ECON. \& ORG. 1, 3 (1995). But see generally Jonathan Rodden \& Susan Rose-Ackerman, Does Federalism Preserve Markets?, 83 VA. L. REV. 1521 (1997) (critiquing market-preserving federalism). 
competition and experimentation, federal systems also allow subnational governments to "serve as semi-independent and entrepreneurial poles of development, both for resource mobilization and for the provision of public goods and services in a manner that is more responsive to citizens' needs and demands than provision by a single central government." ${ }^{\prime 60}$ It has even been asserted that ethnic-based governments "[m]ay be more efficient in the provision of public goods than the state" because they are less prone to face prisoner's dilemma and free-rider problems. ${ }^{61}$ Finally, federalism might offer ethnic groups greater opportunities for control over local resources and revenues and provide a conduit for distributing the benefits of community development among subnational jurisdictions. Daniel Elazar notes:

[B]ecause of the existence of federalism . . . resources are inevitably spread over a number of centers. At the very least, the capital of every federated state has some claim on the national resources, and together they work to prevent the single metropolis syndrome. This means that more people have a chance to benefit from development efforts. At least, it means that some of the worst excesses of resource concentration are eliminated, and a basis for truly national development begins to emerge. ${ }^{62}$

However, federalism is by no means a panacea for ethnically divided societies. First, ethnic federalism requires ethnic groups to be regionally concentrated for effective administrative subnational boundaries to be drawn. ${ }^{63}$ Second, federalism is not without cost; there are financial costs associated with duplication of functions, physical capital development, and diseconomies of scale. ${ }^{64}$ There are also ethnic conflict costs that need to be considered, including tensions with respect to the ethnic composition of the subnational units' civil service and the risk that particular ethnic groups may be incapable of working outside their own region. ${ }^{65}$ Third, federalism has generally been characterized as an unstable form of government - even when not coupled with ethnicity. ${ }^{66}$ Indeed, "virtually every federal state of any standing has had sooner or later to face a concerted bid for secession by one

60. Lapido Adamolekum \& John Kincaid, The Federal Solution: Assessment and Prognosis for Nigeria and Africa, 21 PUBLIUS 173, 183 (1991).

61. Mwangi S. Kimenyi, Harmonizing Ethnic Claims in Africa: A Proposal for Ethnic-Based Federalism, 18 CATO J. 43, 54-58 (1998).

62. ELAZAR, supra note 48, at 252 .

63. See Allen Buchanan, Secession: The Morality of Political Divorce from Fort SUMTER TO LITHUANIA AND QUEBEC 48 (1991) (presenting the "normative nationalist principle" that "political and cultural (or ethnic) boundaries must, as a matter of right, coincide").

64. See HorOWITZ, supra note 34, at 621-22.

65. Id. at 622; see Selassie, supra note 53, at 92

66. See Greg Craven, Of Federalism, Secession, Canada and Quebec, 14 DALHOUSIE L.J. 231, 243 (1991) ("It must be admitted as a simple matter of statistics, the picture for an ardent supporter of federalism is not an encouraging one."). 
or more of its component regions. ${ }^{967}$ Lastly, by structuring a polity along ethnic lines, ethnic federalism has the potential to restrict the mobility of labor, goods, and capital across subnational jurisdictions, ${ }^{68}$ create new economic divisions organized around ethnic lines ${ }^{69}$ and contribute to interjurisdictional wealth disparity. ${ }^{70}$

\section{Polyethnic Rights and Cultural Protections}

Group-differentiated rights focusing on cultural accommodation (also known as polyethnic rights) $)^{71}$ are a third institutional mechanism that protects minority rights. Minority groups often seek recognition of their cultural distinctiveness. Some of these cultural aspects require protections that go beyond individual rights and rely primarily on group membership. ${ }^{72}$ For instance, the South African Constitution - well known for its recognition of the language and cultural rights of minorities - protects the right "to receive education in the official language or languages of [one's] choice"73 and requires the state to take "positive measures to elevate the status and advance the use" of eleven officially identified languages. ${ }^{74}$ These rights are provided out of recognition that minority groups are vulnerable, minority cultures are fragile, and that cultural loss would constitute a substantial blow to members' self-identity. ${ }^{75}$

One possible problem associated with cultural accommodation rights is the potential for entrenchment of ethno-cultural identities into democratic political competition. Some ethnic groups fear that their cultural interests will be overridden unless their interests are integrated into existing state institutions. This can lead to "undifferentiated general demands for accommodationist institutions and policies across the board." ${ }^{" 76}$ One solution to this problem is to use different constitutional structures for the political and cultural spheres. ${ }^{77}$ By accommodating cultural concerns with guarantees of positive and negative cultural rights while basing formal political institutions (such as electoral competition and representation) on integrationist principles, a less ethnicized but more flexible political system

\footnotetext{
67. Id.

68. Selassie, supra note 53 , at 89 .

69. HorowiTz, supra note 34 , at 7-9; Chua, supra note 25 , at 5 .

70. Selassie, supra note 53, at 91-92.

71. See Will Kymlicka, Multicultural Citizenship 30-31 (1995).

72. See, e.g., id. at $110-11$.

73. S. AFr. CONST., $1996 \S 29(2)$.

74. Id. § 6.

75. See Saban, supra note 1, at 906-07.

76. Pildes, supra note 38 , at 193.

77. Id. at 194.
} 
can emerge. ${ }^{78}$ The next section uses these design elements as a springboard to theoretically frame the institutional protection of minority rights in a historical, path dependent context.

\section{A PATH DEPENDENT THEORY OF COLONIAL LEGACIES AND MINORITY RIGHTS}

While the internal self-determination literature has offered a number of thoughtful and flexible institutional arrangements to protect the political and cultural rights of minority groups, its efforts have noticeable and important weaknesses. First, the literature eschews the historical development of minority rights and largely examines the protection of minority rights in a temporal vacuum. Institutions are inherently change resistant. As a result, little theoretical attention has been paid to the origins of these institutions and how they change over time. Second, the literature places a premium on both the design and quality of formal political institutions, but it struggles to explain anomalous cases - in particular, the low levels of minority rights protections in relatively well-institutionalized and robust democracies. Accordingly, this section develops both a theoretical framework and a causal argument that offer a historio-institutional perspective on minority rights protections, and contribute to a budding research agenda that addresses history's effect on states' compliance with human rights obligations. This section proceeds in three parts. First, theories of historical institutionalism and path dependency are outlined as an analytical framework. Next, the colonial legacy literature is engaged, focusing on diverging administrative practices and colonial treatment of ethnicity in Africa. Lastly, these two parts are synthesized to craft a causal argument focusing on the path dependent relationship between ethnic institutionalization under colonial rule and current minority rights protections.

\section{A. Historical Institutionalism and Path Dependency}

While institutionalism has long been entrenched in legal scholarship, ${ }^{79}$ historical institutionalism has only more recently made inroads into legal scholarship. "At its broadest, historical institutionalism represents an

78. South Africa's constitutional system exemplifies this. See generally Christina Murray \& Richard Simeon, Recognition Without Empowerment: Minorities in a Democratic South Africa, 5 INT'L J. CONST. L. 699 (2007).

79. See Edward L. Rubin, The New Legal Process, the Synthesis of Discourse, and the Microanalysis of Institutions, 109 HARV. L. REV. 1393, 1393 (1996).

80. See Philip M. Nichols, Forgotten Linkages-Historical Institutionalism and Sociological Institutionalism and Analysis of the World Trade Organization, 19 U. PA. J. INT'L ECON. L. 461, 461 n.2 (1998); Philip M. Nichols, A Legal Theory of Emerging Economies, 39 VA. J. INT'L L. 229, 239-43 (1999). 
attempt to illuminate how political struggles 'are mediated by the institutional setting in which [they] take place." 81 Sven Steinmo extends the metaphor of the historical institutionalist as an environmental biologist who believes that, in order to understand the specific fate of a particular organism or behavior, he or she must explicitly examine that organism in the ecology or context in which it lives. ${ }^{82}$

Historical institutionalism is closely associated with a distinctive perspective of understanding historical development and the place of institutions in historical context. ${ }^{83}$ Path dependency is the principal mechanism through which historical institutionalism operates. As described by Stephen Krasner:

Historical developments are path dependent; once certain choices are made, they constrain future possibilities. The range of options available to policymakers at any given point in time is a function of institutional capabilities that were put in place at some earlier period, possibly in response to very different environmental pressures. ${ }^{84}$

Institutions are intrinsically change-resistant and "sticky" insofar as once they are created and actors venture down a particular path, they are unlikely to change or reverse course. ${ }^{85}$ This is due primarily to selfreinforcing mechanisms built into existing institutions and the high social and economic costs associated with institutional change. ${ }^{86}$ Thus, many historical institutionalists also divide the flow of historical events into periods of continuity punctuated by "critical junctures"-moments when substantial institutional change takes place and creates a branching point

81. Kathleen Thelen \& Sven Steinmo, Historical Institutionalism in Comparative Politics, in STRUCTURING Politics: Historical InSTITUTIONALISM IN COMPARATIVE ANALYSIS 2 (Sven Steinmo et al. eds., 1992).

82. Sven Steinmo, Historical Institutionalism, in APPROACHES AND METHODOLOGIES IN THE Social Sciences: A Pluralist Perspective 128 (Donatella Della Porta \& Michael Keating eds., 2008).

83. See Peter A. Hall \& Rosemary C. R. Taylor, Political Science and the Three New Institutionalisms, 44 POL. STUD. 936, 941 (1996).

84. Stephen Krasner, Sovereignty: An Institutional Perspective, 21 COMP. POL. STUD. 66, 67 (1988); see also Orfeo Fioretos, Historical Institutionalism in International Relations, 65 INT'L ORG. 367, 375 (2011) (footnote omitted).

85. See Paul Pierson, The Limits of Design: Explaining Institutional Origins and Change, 13 GOVERNANCE 475, 493 (2000) ("Actors do not inherit a blank slate that they can remake at will when their preferences shift or unintended consequences become visible. Instead, actors find that the dead weight of previous institutional choices seriously limits their room to maneuver."); Paul Pierson \& Theda Skocpol, Historical Institutionalism in Contemporary Political Science, in POLITICAL SCIENCE: THE StATE OF THE DisciPLine 703 (Ira Katznelson \& Helen Milner eds., 2002); PAUl PiERSON, Politics IN TIME: History, INSTITUTIONS, AND SOCIAL ANALYSIS 151 (2004).

86. Mariana Prado \& Michael Trebilcock, Path Dependence, Development, and the Dynamics of Institutional Reform, 59 U. TORONTO L.J. 341, 350-53 (2009). 
from which historical development moves onto a new path. ${ }^{87}$ Accordingly, existing institutional relationships have a causal effect on new policies and institutional arrangements.

\section{B. Colonial Legacies}

\section{Constructing Bula Matari?}

The starting point for developing a historical theory of minority rights protection is to conceptualize colonial legacies to better understand how institutional, social, and economic structures developed under colonialism remain deeply embedded in modern institutions. Focusing on African colonialism is particularly useful because of the extent of institutional transformation, breadth of geographic scope, ${ }^{88}$ and variation of legacies within a single colonial state-both between colonies of the same colonizer and of different colonizers. In Africa, the colonial state lasted less than a century in most instances. However, colonialism "totally reordered political space, societal hierarchies and cleavages, and modes of economic production." ${ }^{\prime 9}$ Colonial rule also created arbitrary territorial boundaries when Europeans at the 1884 Conference of Berlin agreed to carve "this magnificent African cake" into pieces. ${ }^{90}$ Indeed, Crawford Young famously describes the African colonial state as the "Bula Matari" or "crusher of rocks." 91 Drawing on legal anthropology, Lauren MacLean attenuates this point and contends that the "new formal state institutions and informal institutions transformed each other over time in a dialectical process of everyday interactions. ${ }^{, 92}$ Nevertheless, there remains strong consensus in the literature that the postcolonial state inherited many of its structures, routines, practices, and normative theories of governance from its colonial masters. ${ }^{93}$

87. Id. at 355-58; see generally DAVID COLliER \& RUTH COLLIER, SHAPING THE POLITICAL ARENA (1991); Stephen D. Krasner, Approaches to the State: Alternative Conceptions and Historical Dynamics, 16 COMP. Pol. 223 (1984).

88. All but two African nations - Liberia and Ethiopia - experienced periods of colonial rule. See, e.g., Ehiedu E.G. Iweriedor, SchOMBURG CTR. FOR RESEARCH IN BlaCK CUltuRE, Africana Age: The Colonization of Africa, http://exhibitions.nypl.org/africanaage/essay-colonization-of-africa.html [https:// perma.cc/348X-WV4L] (last visited Oct. 12, 2016).

89. Crawford Young, The African Colonial State in Comparative Perspective 9 (1994).

90. King Leopold of Belgium is credited with describing Africa this way prior to the Berlin conference. See, e.g., ADAM HochSCHILD, KING LEOPOLD's GHOST: A STORY OF GREED, TERROR, AND HEROISM IN COLONIAL AFRICA 58 (1998).

91. YounG, supra note 89 , at 1, 283.

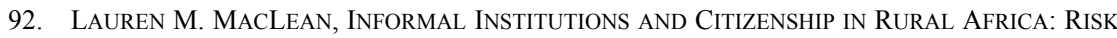
AND RECIPROCITY IN GHANA AND COTE D'IVOIRE 26 (2010).

93. But see JefFrey Herbst, States AND Power in AfricA: Comparative Lessons in AUTHORITY AND CONTROL 4 (2000) (arguing "it was impossible for Europeans to have changed 'everything' in the few decades they ruled Africa. They also had to take Africa's political geography as 
This effect is also seen at the microsocial level, as the "everyday reason of state, as it imposed its logic on the new rulers, incorporated subliminal codes of operation bearing the imprint of their colonial predecessors." $" 94$

Although there are general trends of political, economic, and social transformation under colonial rule, colonial legacies vary considerably due to significant differences in the hegemony, administrative policies, and ideologies of colonizers. ${ }^{95}$ While this Article need not undertake an exhaustive analysis of colonial practices and policies in Africa, the most fundamental differences among colonizers can be illustrated by contrasting Great Britain with other continental European states. The British tended to administer with a "less centralized historical personality, a less thorough impregnation with an earlier absolutist tradition, and a less prefectoral model of regional administration." ${ }^{" 96}$ By comparison, "France stood at the other end of the spectrum, with the powerful Cartesian, Jacobin impulses that are a recurrent refrain in its imperial statecraft." ${ }^{\prime 97}$ The difference between Great Britain's decentralized, indirect rule and the centralized, direct rule of the French has spawned considerable research focusing on the mode of colonial rule as an explanatory variable or source of influence. ${ }^{98}$

In addition to variation of colonial legacy between colonizers, it is important to note that legacies may also vary within the same colonizer and within a particular colonial state. In Daron Acemoglu, Simon Johnson, and James Robinson's classic albeit controversial paper, ${ }^{99}$ they argue that Europeans often transplanted their own institutions when colonizing other parts of the world. Specifically, Europeans constructed low-quality institutions when they sought to extract resources and high-quality

a given because they were unwilling and unable to change the landscape.").

94. Young, supra note 89, at 283; see also MAHMOOD MAMDANI, CitIZEN AND SUBJECT: CONTEMPORARY AFRICA AND THE LEGACY OF LATE COLONIALISM 37-61 (1996) (arguing that colonial rule in the countryside was characterized by "decentralized despotism" exercised by chiefs who owed their authority to their European masters, and that this setup was never effectively dismantled).

95. See YounG, supra note 89 , at 79.

96. Id. at 99 .

97. Id.

98. See, e.g., Lauren M. MacLean, Constructing a Social Safety Net in Africa: An Institutionalist Analysis of Colonial Rule and State Social Policies in Ghana and Cote d'Ivoire, 37 STUD. COMP. INT'L DEV. 64 (2002) (social service provision); MACLEAN, supra note 92 (informal institutions of reciprocity); see generally Edward L. Glaeser \& Andrei Shleifer, Legal Origins, 117 Q.J. ECON. 1193 (2002) (common law/civil law and economic development).

99. See generally Daron Acemoglu et al., The Colonial Origins of Comparative Development: An Empirical Investigation, 91 AM. ECON. REv. 1369 (2001); David Y. Albouy, The Colonial Origins of Comparative Development: An Empirical Investigation: Comment, 102 AM. ECON. REV. 3059 (2012) (criticizing); Daron Acemoglu et al., The Colonial Origins of Comparative Development: An Empirical Investigation: Reply, 102 AM. ECON. REV. 3077 (2012) (defending). 
institutions when they sought to engage in long-term investment. ${ }^{100}$ Extraction was used when conditions were too harsh for colonists to survive for a long period of time because of disease or when valuable resources were abundant and easy to access. ${ }^{101}$ Otherwise, settlers invested for the long-term by transplanting legal, political, and economic institutions of the colonizing government into colonial society. ${ }^{102}$ Using settler mortality as an instrumental variable for historical institutional quality, Acemoglu, Johnson, and Robinson uncovered strong empirical evidence that settler mortality is negatively associated with current wealth. ${ }^{103}$ Additionally, scholars have found that the European share of the population during colonization is a predictor of current wealth. ${ }^{104}$ Accordingly, they argue that their results suggest the importance of the human capital that was brought by early European settlers during colonization. ${ }^{105}$ Adam Chilton and Eric Posner have applied these scholars' arguments to human rights protections, and have found statistically significant correlations with respect to both variables. ${ }^{106}$ Lastly, Catherine Boone contends that there are significant regional (subnational) variations in the patterns of centralization and decentralization of state power. ${ }^{107}$ For instance, the French colonial state in Senegal pursued a decentralized policy of administrative power sharing in the Wolof Groundnut Basin, but pursued a more centralized policy of administrative occupation in Lower Casamance, primarily in response to variations in social hierarchy and resource dependence in the respective rural societies. ${ }^{108}$

\section{Colonialism and the Imagining of Ethnicity}

Colonial states' engagements and interactions with the concept of African ethnicity are particularly relevant to this Article. Ethnicity is not only the "crucible of African politics," 109 but colonialism had a distinctive

100. Acemoglu et al., supra note 99, at 1370.

101. Id.

102. Id.

103. Id.; see generally Daron Acemoglu et al., Reversal of Fortune: Geography and Institutions in the Making of the Modern World Income Distribution, 117 Q.J. ECON. 1231 (2002).

104. See Enrico Spolaore \& Romain Wacziarg, How Deep Are the Roots of Economic Development?, 51 J. ECON. LiterATURE 325, 338-41 (2013); Louis Putterman \& David N. Weil, Post1500 Population Flows and the Long-Run Determinants of Economic Growth and Inequality, 125 Q.J. ECON. 1627, 1677 (2010); William Easterly \& Ross Levine, The European Origins of Economic Development 23-24 (Nat'l Bureau of Econ. Research, Working Paper No. 18162, 2014), http://www.nber.org/papers/w18162.pdf [https://perma.cc/5S5R-F2R4].

105. See Easterly \& Levine, supra note 104, at 2.

106. Chilton \& Posner, supra note 7, at 27-31.

107. Catherine Boone, Political Topographies of the African State 2 (2003).

108. See id. at 43-140; see also MACLEAN, supra note 92, at 26 (focusing on Ghana and Cote d'Ivoire).

109. PATrick Chabal \& JeAn-Pascal Daloz, Africa Works: Disorder as Political 
encounter with respect to ethnicity in Africa. In addition to European colonizers lacking knowledge of African political systems or cultural differences and creating highly heterogeneous, multiethnic states, African colonialism was accompanied by systematic theories of European racial superiority. ${ }^{110}$ According to Michael Crowder, "[t]he portrait of Africa painted by the colonial powers was one of a people who on the eve of occupation were politically decentralised, living in small villages, often naked, dominated by witchcraft, living in terror of their neighbours."111 Accordingly, European occupation and domination of Africans was infamously described in terms of a "sacred trust" or "The White Man's Burden."112

The fact that the colonial state cemented the importance of ethnic identities in post-colonial Africa is not controversial. ${ }^{113}$ What is contested in the literature - similar to broader theories about colonial administration - is the extent to which colonial states created, transformed, and institutionalized ethnicity. Initially, the "colonial invention of tribes" school of thought dominated the literature. ${ }^{114}$ This ideology held that "Europeans implicitly believed their concept of ethnicity to be the natural order and not merely one convention amongst others used to make sense of the world." ${ }^{\prime 15}$ Based on this belief, divide and rule tactics of colonial predecessors left behind a crippling legacy of intergroup tensions and communal mistrust and placed "an ethnic curse" on many postcolonial regimes. ${ }^{116}$ Modern theories have focused less on colonial agency. ${ }^{117}$ Instead, the literature has gravitated

InSTRUMENT 49 (1999); see also Goran Hyden, Problems and Prospects of State Coherence in Africa, in State Versus Ethnic Claims: African Policy Dilemmas 70 (Donald Rothchild \& Victor A. Olorunsola eds., 1983) (describing ethnicity as an "essential aspect of African politics").

110. See YounG, supra note 89, at 280 ("[T] he creation of the African colonial state coincided with the historical zenith of virulent racism.").

111. Michael Crowder, West Africa Under Colonial Rule 12 (1968).

112. Id. at 5; see also YOUNG, supra note 89, at 98 ("The conviction of African 'savagery' permeated European thought at the moment of colonial state construction.").

113. See DANiel N. Posner, Institutions AND Ethnic Politics In Africa 23 (2005) (contending that to argue otherwise would likely be controversial).

114. See Carola Lentz, Ethnicity AND the Making of History in Northern GHana 6 (2006).

115. Patrick Harries, Exclusion, Classification, and Internal Colonialism: The Emergence of Ethnicity Among the Tsonga-Speakers of South Africa, in THE CREATION OF TRIBALISM IN SOUTHERN AFrICA 82, 90 (Leroy Vail ed., 1989); see also David Killingray, Imagined Martial Communities: Recruiting for the Military and Police in Colonial Ghana, 1860-1960, in ETHNICITY IN GHANA, supra note 5, at 119 (applying this principle to British colonialism).

116. John Stone, Ethnicity Versus the State: The Dual Claims of State Coherence and Ethnic SelfDetermination, in STATE Versus ETHNIC Claims, supra note 109, at 85.

117. See Terence Ranger, The Invention of Tradition Revisited: The Case of Colonial Africa, in LEGITIMACY AND THE STATE IN TWENTIETH-CENTURY AFRICA 62 (Terence Ranger \& Olufemi Vaughan eds., 1993) (noting that the convention of "invention" exaggerates the mechanical, authorial aspects of 
towards the concept of "imagination"118 and has focused either on the creation of new identities or the reconfiguration of old ones-processes that involve many different actors with diverse intentions and interpretations. ${ }^{119}$ Nevertheless, the colonial state had important yet varied roles in transforming and institutionalizing ethnicity, which this Article contends had causal consequences for current protections of minority rights.

\section{Linking Colonial Legacies and Minority Rights}

Synthesizing the framework of historical institutionalism and the literature on colonial legacies, this Article argues that varying patterns of colonial institutional practices towards ethnic groups have had a causal, path dependent effect on current minority rights protections. Unlike Adam Chilton and Eric Posner's research that alludes to the quality of historical institutions and their effects on human rights, ${ }^{120}$ this Article adopts a more subtle, contextual focus on how historical institutions are structured. In addition to imagining and transforming ethnic groups in myriads of ways, ${ }^{121}$ colonial states also institutionalized and politicized ethnic groups to varying extents. Just as ethnicity can be organized and disorganized, ${ }^{122}$ ethnicity can also be politicized and depoliticized. In doing so, colonial institutions either fostered or constrained ethnicity as a political cleavage. Thus, in the colonial period, institutional foundations were built that placed particular ethnic groups into different positions of political power and salience.

In the post-colonial period, a variety of ethnic paradigms have been recognized. ${ }^{123}$ One option was to "recognize the dominant position held by specific 'intermediary' groups, and thus identify the character of the newly emergent state with their assumed cultural, economic, and social preeminence." 124 A second type came "in the form of a sudden switch of ethnic partnerships, soon accompanied by a drastic redistribution of power." ${ }^{125}$ This

creation as well as the functionality and rigidity of the end-product); CHABAL \& DALOZ, supra note 109, at 57 (" $[\mathrm{I}] \mathrm{t}$ is not possible . . to assert an 'iron law' on the construction of ethnicity under colonial rule.").

118. See generally BENEDICT ANDERSON, IMAGINED COMMUNITIES: REFLECTIONS ON THE ORIGIN AND SPEED OF NATIONALISM (1983).

119. See Lentz \& Nugent, supra note 5, at 6; CHABAL \& DALOZ, supra note 109, at 56-57.

120. Chilton \& Posner, supra note 7.

121. See LENTZ, supra note 114 , at 7-8.

122. See Naomi Chazan, Patterns of State-Society Incorporation and Disengagement in Africa, in The Precarious Balance: State And Society in Africa 121, 134 (Donald Rothchild \& Naomi Chazan eds., 1988).

123. See René Lemarchand, The State and Society in Africa: Ethnic Stratification and Restratification in Historical and Comparative Perspective, in STATE VERSUS ETHNIC CLAIMS, supra note 109 , at 58 .

124. Id.

125. Id. 
Article argues, based on principles of historical institutionalism and colonial legacy, that these differing ethnic paradigms map neatly onto the ethnically (de)politicized institutions created under colonial rule. Because ethnicity is conceptualized as a dynamic, rational, and instrumental form of political behavior, $^{126}$ in the new colonial state, politicized ethnic groups will reproduce institutions, policies, and discourse that serve their political interests, while depoliticized ethnic groups will minimize the salience of ethnic cleavages. Thus, the creation of an ethnic political hegemony prior to independence often leads to an institutional legacy where ethnicity is utilized in an instrumental, political, and discriminatory fashion.

Accordingly, when ethnicity is institutionalized and politicized during colonial rule, less appreciation of minority rights is anticipated in the postcolonial period, not only because ethnicity is a salient political cleavage, but also because ethnic groups are often placed into asymmetrical political power relationships. Thus, in these instances, ethnic majorities in power will likely have less respect for minority rights. Conversely, when ethnicity is depoliticized in the colonial period, greater protection of minority rights can be anticipated in the post-colonial period because ethnicity has not emerged as a salient political cleavage and no ethnic group has a historically privileged position of political power compared to other ethnic groups. The next section provides qualitative and quantitative support for this historical and path dependent argument of minority rights protection.

\section{DIVERGING PATHS OF MINORITY RIGHTS IN BOTSWANA AND GHANA}

\section{A. Research Design}

This Article utilizes a comparative analysis of two heuristic case studies $^{127}$-Botswana and Ghana - to support the claim that colonial legacies of ethnic (de)politicization have causal effects on current minority rights protections. For empirical support, this Article draws on qualitative evidence from a structured comparative historical analysis of Botswana and Ghana's treatment of ethnicity, post-independence political discourse focusing on ethnicity, laws and policies towards minority groups, and quantitative data of current minority rights protections from the Minorities

126. See Robert H. Bates, Modernization, Ethnic Competition, and the Rationality of Politics in Contemporary Africa, in StATE Versus ETHNiC Claims: AfricAn Policy Dilemmas 152, 152 (Donald Rothchild and Victor A. Olorunsola, eds., 1983) (describing ethnic groups as "coalitions which have been formed as part of rational efforts to secure benefits created by the forces of modernization").

127. See Alexander L. George \& Andrew BennetT, Case Studies AND Theory DEVELOPMENT IN THE SOCIAL SCIENCES 75 (2005) (noting that "[h]euristic case studies inductively identify new variables, hypotheses, causal mechanisms, and causal paths") (emphasis omitted). 
at Risk dataset. Botswana and Ghana are used as cases due to their differences in minority rights protections despite many institutional and historical similarities. ${ }^{128}$ The countries' institutional and historical similarities are important for case selection and comparative analysis because they effectively control for competing hypotheses that could otherwise explain variations in current minority rights protections. Both Botswana and Ghana are former British colonies governed under indirect rule. This is relevant because ethnicity is often a more salient cleavage in former-British colonies where society was more ethnicized and less assimilated than, for instance, French colonies that focused on the nuclear family system as the unit of governance. ${ }^{129}$ Moreover, both Botswana ${ }^{130}$ and Ghana $^{131}$ have been lauded as robust, well-institutionalized democracies. Despite these similarities, non-Tswana minorities in Botswana-especially the San-have been marginalized throughout the country's history, while Ghana has a strong record of minority rights protections. As history shows, these divergent paths reflect differing institutional patterns of ethnic politics developed under colonial British rule that were later reinforced and perpetuated following independence.

\section{B. Botswana: Imagined and Instrumentalized Ethnic Homogeneity}

\section{Pre-Independence: Tswana as Intermediary}

Despite a common perception articulated by the state of Botswana, the country is not ethnically homogenous. Officially, the Tswana are the ethnic majority of Botswana at seventy-nine percent, ${ }^{132}$ but minorities arguably constitute well over half the nation's population. ${ }^{133}$ Beginning during the precolonial period and extending through British colonial rule, the Tswana have been institutionalized as the dominant political and social ethnic group in

128. Although Botswana and Ghana share some differences with respect to the extent of pre-colonial ethnic hegemony, I believe such differences do not obviate the most similar systems nature of the cases or the theoretical validity of my argument.

129. See MACLEAN, supra note 92, at 100.

130. See, e.g., YOUNG, supra note 89, at 2 (describing as "capably ruled"); James A. Robinson \& Q. Neil Parsons, State Formation and Governance in Botswana, 15 J. AFR. ECON. 100, 100, 103 (2006) (describing the state as legal-rational); Daron Acemoglu et al., An African Success Story: Botswana, in In SEARCh of Prosperity: ANALYTIC NARRATIVES ON ECONOMIC GROWTH 80, 84 (Dani Rodrik ed., 2003) (emphasizing the quality of institutions).

131. See, e.g., MacLean, supra note 98, at 84-85 (describing as a model of democratic consolidation).

132. Central Intelligence Agency, CiA World Fact BoOK-Botswana, https:// www.cia.gov/library/publications/the-world-factbook/geos/bc.html [https://perma.cc/3A2M-6FAU] (last visited Oct. 12, 2016).

133. Jacqueline Solway, “Culture Fatigue”: The State and Minority Rights in Botswana, 18 IND. J. GLOBAL LEGAL STUD. 211, 214 (2011). 
Botswana. For instance, the kgotla - the traditional village gathering place and central institution in Tswana local governance that has been lauded as a cultural manifestation of democratic consensus and a core reason behind Botswana's broader political and economic success ${ }^{134}$ — was highly exclusionary. As James Denbow and Phenyo Thebe note:

[W]omen, minors, and unmarried men . . . were excluded from the deliberations. Only males who were members of the dominant Tswana ethnic group could participate in the kgotla. Subservient peoples, such as the Kgalagadi and Sarwa, had no right to voice an opinion or to take part in important decisions. Women were also excluded regardless of their ethnicity, and in even recent years some "traditional" kgotla meetings may be called that exclude women. ${ }^{135}$

Under British colonial rule, ethnicity was further developed and institutionalized as a political cleavage. As a result, Tswana political domination over non-Tswana minority groups was crystallized. The British recognized the Tswana as their intermediary in Botswana because, upon arrival, it appeared that the Tswana were already in charge. ${ }^{136}$ Under the indirect rule system of "Native Reserves" and "Crown Lands," Britain parceled the land without making land provisions for the San, ${ }^{137}$ despite their having lived in southern Africa for over 40,000 years. ${ }^{138}$ As colonial intermediaries, the Tswana held nearly complete control over these decentralized units of governance. ${ }^{139}$ As a result, non-Tswana minority groups, including the San, fell into subjugation under both British colonial officials and the Tswana ethnic majority. ${ }^{140}$

Given the importance of hunting to their existence and culture, land reform is an essential policy issue for the San. As another scholar has noted, "since virtually no land had been expressly set aside for San groups, an especially important development in 1961 was the creation of the Central Kalahari Game Reserve ("CKGR") - the largest protected area in Botswana

134. See Stephen R. Lewis, Jr., Explaining Botswana's Success, in Developing Cultures: CASE STUDIES 3, 7 (Lawrence Harrison \& Peter L. Berger eds., 2006).

135. James Denbow \& Phenyo C.Thebe, Culture and Customs of Botswana 22. The Sarwa is another name for the San indigenous group in Botswana. See also Olmsted, supra note 8, at 815-16 (describing the exclusionary tendencies of the kgotla).

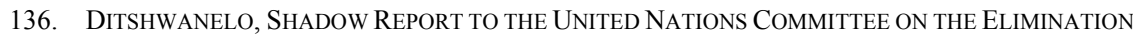
OF RACIAL DiscriminATION (CERD), § 2(a) (68th Session, Geneva, Mar. 3-6, 2006).

137. Olmsted, supra note 8, at 825-26.

138. Nick Crumpton, 'Earliest' Evidence of Modern Human Culture Found, BBC NEWS (July 12, 2012), http://www.bbc.com/news/science-environment-19069560; see also J.D. LEWIS-WILLIAMS, DisCOVERING SOUTHERN AFRICAN ROCK ART 17-18 (1990); Kenneth Good, At the Ends of the Ladder: Radical Inequalities in Botswana, 31 J. MoD. AFR. STUD. 203, 206 (1993).

139. Olmsted, supra note 8 , at 825.

140. Id. at 862 . 
and one of the largest in Africa." ${ }^{141}$ Colonial regulations limited San hunting privileges and proscribed CKGR residents from keeping domestic animals, even though some San traditionally utilized dogs in hunting. ${ }^{142}$ However, the British colonial administration accorded the major Tswana tribes substantial autonomy in hunting regulation, but gave no such autonomy to San groups. ${ }^{143}$ These ethnic inequities with respect to land and hunting rights illustrate the development of ethnicity as a salient political cleavage in Botswana and an imbalance of institutional power between the Tswana and non-Tswana groups. They also foreshadow the Botswana government's later rationalization of policies that further limited the rights of CKGR residents under the guise of protecting wildlife. ${ }^{144}$

\section{Post-Independence: Tswana as Hegemon}

Both the structure and the politicization of formal political institutions along ethnic lines from colonial rule were preserved in post-independence Botswana. ${ }^{145}$ Accordingly, Tswana institutional ethnic hegemony carried over into the discourse, laws, and politics of the newly independent state. Botswana premised its nation-building efforts on an overstated assertion of ethnic homogeneity because of the significant representation of the Tswana. ${ }^{146}$ Importantly, the boilerplate bill of rights provided by Britain during colonialism carried over to post-colonial Botswana, emphasizing a more integrationist approach. ${ }^{147}$ Botswana's first president, Sir Seretse Khama, emphasized a similar approach and focused heavily on fostering national unity in the country through a discourse of "non-racialism." However, given the historic and institutionalized political power of the

141. Id. at 828 n. 161; see also Christian Erni, Resettlement of Khwe Communities Continues, $3 / 4$ INDIGENOUS AFFAIRS 8 (1997).

142. Kristyna Bishop, Squatters on Their Own Land: San Territoriality in Western Botswana, 31 COMP. \& INT'L L.J. S. AFR. 92, 113 (1997).

143. Clive Spinage, History and Evolution of the Fauna Conservation laws of Botswana 11 (1991) (noting that the first Assistant Commissioner was directed "not to interfere with the Native Administration; the Chiefs are understood not to be desirous of parting with their rights of sovereignty, nor are Her Majesty's Government by any means anxious to assume the responsibilities of it").

144. See id. at 60-61.

145. See RoTHCHILD, supra note 25 , at 43 (“"[L]eaders in Botswana ... essentially accepted existing clientelistic practices and preserved intact the basic laws and structures inherited from the colonizers. . . .”); Crawford Young, The Colonial State and its Political Legacy, in THE PRECARIOUs BALANCE, supra note 122, at 56 (noting the long survival of the institutional synthesis of the terminal state in Botswana).

146. Sidsel Saugestad, The Inconvenient Indigenous: Remote AREA Development in Botswana, Donor Assistance, AND the First PEOPle of the KALAHARi 69 (2001).

147. Charles Parkinson, Bills of Rights and Decolonization: The Emergence of DOMESTIC HUMAN RIGHTS INSTRUMENTS IN BRITAIN'S OVERSEAS TERRITORIES 256 n.50 (2007).

148. Lewis, supra note 134, at 12 (describing Khama's party as "national, nontribal and nonracial"). 
Tswana and the strong political presence of the Tswana at independence, nationalism in Botswana-whether consciously or not - was created by and for the Tswana people. ${ }^{149}$ This false sense of homogeneity has persisted throughout Botswana's history. For instance, in 2006, Botswana voted in favor of delaying a vote for a United Nations Declaration on the Rights of Indigenous Peoples based on the argument that "[t]he country is made up of indigenous people, who could not be against themselves. If a shoe did not fit, only the person wearing the shoe would feel the pain." 150 Accordingly, the creation and articulation of nationalism predicated on citizenship rather than ethnicity in Botswana can be seen as an instrumental use of ethnicity by the historically institutionalized ethnic majority, the Tswana. ${ }^{151}$ As a result of this discursive strategy, a false consciousness of national ethnic homogeneity has persisted alongside an ignorance of existing ethnic heterogeneity in Botswana. ${ }^{152}$

Botswana's false sense of ethnic homogeneity has resulted in the codification of Tswana-based nationalism into the Constitution at independence. Of particular importance is the Botswana Constitution's paradoxical ethnicity-blind nondiscrimination regime. Section 15(1) of the Constitution states that "no law shall make any provision that is discriminatory either of itself or in its effect," 153 and subsection (2) provides that "no person shall be treated in a discriminatory manner by any person acting by virtue of any written law or in the performance of the functions of any public office or any public authority." defined in subsection (3):

[A]ffording different treatment to different persons, attributable wholly or mainly to their respective descriptions by race, tribe, place of origin, political opinions, colour or creed whereby persons of one such description are subjected to disabilities or restrictions to which persons of another such description are not made subject or are accorded privileges or advantages which are not accorded to persons of another such description. ${ }^{95}$

149. SAUGESTAD, supra note 146 , at 72 .

150. Press Release, General Assembly, Third Committee Approves Draft Resolution on Right to Development; Votes to Defer Action Concerning Declaration on Indigenous Peoples, GA/SHC/3878 (Nov. 28, 2006).

151. See Amelia Cook \& Jeremy Sarkin, Who Is Indigenous?: Indigenous Rights Globally, in Africa, and Among the San in Botswana, 18 TUL. J. INT'L \& COMP. L. 93, 119-20 (2009) ("Of course, this objective was made easier by Tswana domination in the political and economic structures, and a policy of non-racialism is questionable in a country where a single ethnic group maintains most of the power.").

152. SAUGESTAD, supra note 146 , at 69 .

153. BOTSWANA CONST. $§ 15(1)$.

154. Id. $\S 15(2)$.

155. Id. $\S 15(3)$. 
Accordingly, the language of this provision, with its focus on differential treatment, appears to make it difficult for affirmative measures to be enacted in favor of certain ethnic or racial groups. Additionally, the kgotla - the Tswana's model of local government and an exclusionary wolf in democratic sheep's clothing - was formally incorporated into the national legal system. ${ }^{156}$ Although President Khama's efforts to foster unity and nonracialism have been lauded, ${ }^{157}$ a number of minority groups, including the San, have been harmed by this nationalist agenda. ${ }^{158}$ The next section specifically addresses the treatment of minority rights in Botswana.

\section{Minority Rights: Pseudo Assimilationism}

Botswana exemplifies a state that appears neutral between various groups by affording individual rights to all citizens. However, the country systematically privileges the majority national group in certain fundamental ways. ${ }^{159}$ Indeed, Botswana has been criticized for its marginalization of minority ethnic groups, particularly the San, an indigenous group that has occupied the Kalahari Desert region as hunters and gatherers for over 40,000 years, making them the oldest and arguably most culturally unique ethnic group in Botswana. ${ }^{160}$ Due to significant discrimination and marginalization by the Tswana-dominated government of Botswana, the San "are widely recognized as the most impoverished, disempowered, and stigmatized ethnic group in southern Africa."161 The San have been "denied many of the benefits" of Botswana's economic development and, consequently, "[m]any San in Botswana continue to be poor, with high unemployment rates, high infant mortality, high incarceration rates, low literacy levels, and few assets." $" 162$

The Minorities at Risk ("MAR") dataset confirms the marginalization and discrimination of the San. Although MAR accounts for seventy-one variables, two are particularly noteworthy for this Article-Political Discrimination and Economic Discrimination. These are two of six variables used by MAR to describe disadvantages associated with ethnocultural groups and these variables measure access to two fundamental sets of human

156. See PAul Nugent, Africa SinCe IndEPENDENCE 128 (2004).

157. See, e.g., SAUGESTAD, supra note 146, at 28, 77.

158. DitshWANElo, SupPlementary RePort FOR THE COMMITTEE ON THE Elimination of RACIAL DISCRIMINATION 3 (2002).

159. Solway, supra note 133, at 216 (quoting Will Kymlicka, Ethnicity in the USA, in THE ETHNiCITY READER 229, 231 (Montserrat Guibernau \& John Rex eds., 1997)).

160. DitshWANELO, supra note 136, § 2(a); DitshWANELO, supra note 158, at 3.

161. Renee Sylvain, "Land, Water, and Truth": San Identity and Global Indigenism, 104 AM. ANTHROPOLOGIST 1074, 1074 (2002).

162. Olmsted, supra note 8 , at 802. 
rights: political representation and beneficial socioeconomic conditions. ${ }^{163}$ Political Discrimination ("POLDIS") measures the extent to which "group members are or have been systematically limited in their enjoyments of political rights or access to political positions by comparison with other groups in their society." $" 164$ It is coded on a five-category ordinal scale of severity. ${ }^{165}$ Last updated in 2006, the San received a POLDIS rating of three, ${ }^{166}$ indicating that there is "[s]ubstantial underrepresentation due to prevailing social practice by dominant groups" and that "[f]ormal public policies . . . are neutral or, if positive, inadequate to offset discriminatory practices." "167 Second, Economic Discrimination ("ECDIS") measures the extent to which group members "are or have been systematically excluded from access to desirable economic goods, conditions, or positions that are open to other groups in their society." 168 It is coded on a similar five-category scale as POLDIS. ${ }^{169}$ The San also received an ECDIS rating of three, ${ }^{170}$ indicating that there is "[s]ubstantial poverty and underrepresentation due to prevailing social practice by dominant groups" and that "[f]ormal public policies . . . are neutral or, if positive, inadequate to offset active and

163. Minorities at Risk Project, Minorities at Risk Dataset: Botswana: San Bushmen, UNIV. OF MD., COllege PARK, CTR. FOR INT'L DeV. \& CONFliCt MGMT., http://www.mar.umd.edu/assessment. asp?groupId=57101 [https://perma.cc/DZ2H-LCMJ] (last visited Oct. 9, 2016) [hereinafter San MAR data].

164. TED Robert GURR, MinORITIES AT RISK 46 (1993).

165. The coding for POLDIS is as follows: 0: No discrimination; 1: Substantial under-representation in political office and/or participation due to historical neglect or restrictions. Explicit public policies are designed to protect or improve the group's political status; 2: Substantial under-representation due to historical neglect or restrictions. No social practice of deliberate exclusion. No formal exclusion. No evidence of protective or remedial public policies; 3: Substantial under-representation due to prevailing social practice by dominant groups. Formal public policies toward the group are neutral or, if positive, inadequate to offset discriminatory social practices; 4: Public policies (formal exclusion and/or recurring repression) substantially restrict the group's political participation by comparison with other groups. Minorities at Risk Project, Univ. OF Md., College PARK, Ctr. FOR InT'L DeV. \& Conflict Mgmt., Minorities at Risk (MAR) Codebook Version 2/2009, 11, http://www.mar.umd.edu/data/mar_codebook _Feb09.pdf [https://perma.cc/CUB2-6UL6] (last visited Oct. 9, 2016) [hereinafter MAR Codebook].

166. San MAR data, supra note 163 .

167. GURR, supra note 164 , at 47.

168. Id. at 43 .

169. The coding for ECDIS is as follows: 0: No discrimination; 1: Significant poverty and underrepresentation in desirable occupations due to historical marginality, neglect, or restrictions. Public policies are designed to improve the group's material well-being; 2: Significant poverty and underrepresentation due to historical marginality, neglect, or restrictions. No social practice of deliberate exclusion. Few or no public policies aim at improving the group's material well-being; 3: Significant poverty and under-representation due to prevailing social practice by dominant groups. Formal public policies toward the group are neutral or, if positive, inadequate to offset active and widespread discrimination; 4: Public policies (formal exclusion and/or recurring repression) substantially restrict the group's economic opportunities by contrast with other groups. MAR Codebook, supra note 165, at 11 .

170. San MAR data, supra note 163 . 
widespread practices of discrimination." ${ }^{171}$ MAR provides important insight into the low level of minority rights protection in Botswana. These insights may even be understated because the data does not take into consideration issues of particular importance to the San, such as land rights, ${ }^{172}$ and more recent minority rights claims made by the San, to which the Article now turns.

For the last two decades, the San have brought a number of claims against the Government of Botswana involving land access and resource rights in the CKGR. Following the discovery of diamonds in the early 1980s, the Government of Botswana coerced and then forced virtually all of the San to leave the CKGR in three major clearances in 1997, 2002, and 2005. ${ }^{173}$ These San now live in resettlement camps outside the reserve where alcohol, depression, and disease are rampant. ${ }^{174}$ As a result, the San initiated legal action before the High Court of Botswana in Sesana v. Attorney General. ${ }^{175}$ The San lobbied three substantive claims against the Government of Botswana. First, the San claimed the Government of Botswana should be obliged to reinstate the basic services to the CKGR that were terminated in January 2002 and to maintain those services. ${ }^{176}$ Second, they argued that the Government unlawfully deprived them of their land and therefore must restore it to their lawful possession. ${ }^{177}$ Third, the San claimed the Government refused to issue Special Game Licenses to San living in the CKGR and prohibited them from entering the CKGR even with permitsactions which were unlawful and unconstitutional. ${ }^{178}$

Importantly, the Government of Botswana, echoing pre-colonial policies and an instrumental post-colonial discourse of national welfare, proffered two justifications for its forced relocation of the San. First, it argued that "removing the San is critical to protecting the wildlife and ecology of the Reserve because the San way of life, specifically hunting,

171. GURR, supra note 164 , at 45 .

172. Although not present in the 2006 data, MAR used to measure ecological stress by coding"the presence and severity of three conditions: competition with other groups for settlement of vacant lands, dispossession from land by other groups, and forced internal resettlement." This variable, ECOSTRESS, was coded as a three-category ordinary variable $(1=$ minor, $3=$ serious $) . I d$. at $49-50$. The San received a score of 3 for ECOSTRESS. Id. at tbl.A.11.

173. Tribes and Campaigns: The Bushmen, SURVIVAL INTERNATIONAL, http:// www.survivalinternational.org/tribes/bushmen [https://perma.cc/FGX4-9SYL].

174. Id.

175. Sesana v. Att'y Gen., (52/2002) [2006] BWHC (Bots.), http://www.saflii.org/bw/cases/ BWHC/2006/1.html [https://perma.cc/JGX5-G6V5]..

176. Id. at 455 .

177. Id.

178. Id. at 456. 
"interferes with conservation.",179 Second, "the [government argued] that the San must 'develop' themselves, something that they cannot do if left to their traditional lifestyles within the Reserve." ${ }^{180}$ In light of the sophisticated management regime implemented in the Okavango Delta by the Government of Botswana that successfully balances environmental protection and indigenous livelihood, Kenneth Good has suggested the Government's relocation was specifically tied to mineral wealth. ${ }^{181}$ In 2006, the High Court ruled in the San's favor on every complaint but the first-relating to the provision of basic services - because the San were adequately informed with respect to their termination. ${ }^{182}$ However, the Government of Botswana has remained uncooperative in implementing the Court's ruling. ${ }^{183}$ In fact, the U.S. Department of State criticized "[ $\mathrm{t}$ ]he government's continued narrow interpretation" of the 2006 decision in its 2009 Human Rights Report on Botswana. $^{184}$

In 2010, the San brought legal action against the Government of Botswana before the High Court regarding their right to access water inside the CKGR. ${ }^{185}$ The cause of action stemmed from the Government of Botswana's refusal to open a sealed borehole that ultimately forced the San to transport water hundreds of miles. ${ }^{186}$ Ruling against the San, Justice Lakhvinder Walia stated that the San "have become victims of their own decision to settle an inconveniently long distance from the services and facilities provided by the government." ${ }^{187}$ The San later appealed and lost. ${ }^{188}$ At both the regional and international level, these adverse judgments against the San have been met with significant criticism. Following Jusice Walia's ruling, the Special Rapporteur on Indigenous Rights noted in his 2010 report on Botswana that:

179. Sarkin \& Cook, supra note 8 , at 15 .

180. Id.

181. Kenneth Good, Bushmen AND Diamonds: (Un)Civil SOCIETy In Botswana 20 (2003).

182. Sesana, supra note 175 , at 322.

183. Lucia Van der Post, Bushwhacked, TiMES ONLINE (Sept. 19, 2007), http://www.timesonline.co. uk/tol/news/world/africa/article2482706.ece.

184. U.S. DEP’T OF STATE, 2009 HUMAN Rights REPORT: BOTSWANA 1 (2010).

185. Mosetlhanyane v. Att'y Gen. [2010] BLR 372 (HC) (Bots.).

186. Mark Tran, Kalahari Bushmen to Appeal Against Court Ban on Well in Game Reserve, GUARDIAN (July 22, 2010), https://www.theguardian.com/world/2010/jul/22/kalahari-bushmenbostwana-well-court-appeal [https://perma.cc/AH52-77YY].

187. Tshireletso Motlogelwa, Basarwa Lose Another One, MMEGIONLINE (July 22, 2010), http://www.mmegi.bw/index.php?sid=1\&aid=3659\&dir=2010/July/Thursday22 [https://perma.cc/595P$6 \mathrm{HBX}]$

188. Mosetlhanyane v. Att'y Gen, Appeal No. CACLB-074-10 (Ct. App. Jan. 27, 2011) (Bots.), http://assets.survivalinternational.org/documents/545/bushmen-water-appeal-judgement-jan-2011.pdf [https://perma.cc/A9PX-MALD]. 
The Government should fully and faithfully implement the Sesana judgment and take additional remedial action in accordance with international standards relating to the removal of indigenous peoples from their traditional lands. Such remedial action should include, at a minimum, facilitating the return of all those removed from the reserve who wish to do so, allowing them to engage in subsistence hunting and gathering in accordance with traditional practices, and providing them the same government services available to people of Botswana elsewhere, including, most immediately, access to water . . Indigenous people who have remained or returned to the reserve face harsh and dangerous conditions due to a lack of access to water, a situation that could be easily remedied by reactivating the boreholes in the reserve. The Government should reactivate the boreholes or otherwise secure access to water for inhabitants of the reserve as a matter of urgent priority. ${ }^{189}$

Ultimately, such policies are grounded in a historical and path dependent politicization of ethnicity and institutionalization of the Tswana as the ethno-political hegemon during colonial rule.

\section{Ghana: Depoliticized yet Conscious Ethnicity}

\section{Pre-Independence: The Mismatch of Ethnicity and Tribe}

Like Botswana, Ghana was a British colony administered under a policy of indirect rule. Accordingly, "[t]he Gold Coast was generally conceived by the British as constituting a federation of "native states.",190 Unlike Botswana, however, British colonial administrators took a fundamentally different approach with respect to the political organization of, and policies towards, ethnic groups in Ghana. While the British in Botswana reified, politicized, and institutionalized existing ethnic cleavages and consequently created an ethno-political hegemon in the Tswana, Ghanaian society presented a fundamental mismatch between ethnicity and political organization. Ethnicity and politics did not neatly fit together and thus did not produce ethnic cleavages as in in Botswana. The absence of ethnic cleavages also led to the lack of an ethno-political intermediary role similar to that held by the Tswana in Botswana. This political attenuation of ethnicity in Ghana has created a post-independence national discourse that is devoid of ethnic divisiveness, a set of policies that are highly self-

189. James Anaya, Report of the Special Rapporteur on the Situation of Human Rights and Fundamental Freedoms of Indigenous People, The Situation of Indigenous Peoples in Botswana, $99197-$ 98 U.N. Doc. A/HRC/15/37/Add.2 (June 2, 2010); see also Press Release, African Commission on Human and Peoples' Rights, Press Release on the Situation Facing the Bushmen of the Central Kalahari Game Reserve in Botswana, UN Press Release ACHPR/08/d74 (Aug. 10, 2010) (noting that "[r]efusal to allow the Bushmen to use their existing borehole at Mothomelo can only be interpreted as a clear sign that the Government of Botswana is determined to continue what is perceived as a policy of keeping the Bushmen from returning home").

190. Lentz \& Nugent, supra note 5, at 15. 
conscious with respect to ethnic pluralism and inclusion, and relatively high levels of minority rights protections.

The British effectively laid the foundations for modern day ethnic identities in Ghana by forming chiefdoms under colonial policies and by adopting the "tribe" as an essential normative concept. ${ }^{191}$ These policies speak to a larger discourse on colonial ethnic mapping projects that are "fundamentally about the power to name others [and are] increasingly bound up with an imaginary knowledge of the relationship between ethnic identities and socio-geographic space." "192 The British model was based on the belief that "every African belonged, from birth to death, in a singular tribe" - a population group linked by descent, a common language, and living on a particular territory - "that was clearly distinct from neighboring tribes through physiology, language, and culture." ${ }^{193}$ The fundamental problemone which the more perceptive British colonial administrators and anthropologists themselves realized - is that the concept of the tribe "did not really capture the reality of physical mobility, overlapping networks and multiple group membership. [The anthropologists] knew that the boundaries of language, territory and descent hardly ever coincided." 194

Thus, the tribe, itself a faux-monolithic concept that in reality cut across pre-existing ethnic groups, became the fundamental conceptual unit of colonial governance in Ghana. Ethnic alignments were further redefined by "tinkering with rural power structures" and codifying chieftaincy structures as functions of indirect rule. ${ }^{195}$ The linkage of falsely monolithic "tribes" to the politico-bureaucratic concept of the "native state" has been the "distinguishing feature of the ethnic experience in twentieth-century Ghana."196 Ultimately, recognizing native states, rather than crystallizing extant ethnic cleavages, further reinforced ethnic fragmentation and political attenuation: "[ $\mathrm{t}]$ he native states were not an agglomeration of tribes, but rather entities, whose borders were determined by factors quite different

191. Id. at 9; see also MACLEAN, supra note 92, at 107 (identifying that "the British dedicated significant time and resources for colonial anthropologists to study, understand, and classify the different tribal groups in each colonial territory"); FREDERICK COOPER, DECOLONIZATION AND AFRICAN SOCIETY: THE LABOR QUESTION IN FRENCH AND BRITISH AFRICA 49-50 (1996) (highlighting how the "ideological power of the "tribe"" shaped colonial policies) (internal citation omitted).

192. Eric Worby, Maps, Names, and Ethnic Games: The Epistemology and Iconography of Colonial Power in North-Western Zimbabwe, 20 J.S. AFR. STUD. 371, 371 (1994).

193. See Carola Lentz, Contested Identities: The History of Ethnicity in Northwestern Ghana, in ETHNICITY IN GHANA, supra note 5, at 137-38; LENTZ, supra note 114, at 75.

194. Lentz \& Nugent, supra note 5, at 9; see also LENTZ, supra note 114, at 75 (focusing on the "overlapping identities and fuzzy boundaries" of the Black Volta region specifically).

195. Lentz \& Nugent, supra note 5, at 18.

196. Id. at 10 . 
from ethnic ones, the ethnic labels being attached ex post facto."197 Thus, at the conceptual and institutional levels, indirect rule produced a fundamentally different administrative policy with respect to ethnicity in Ghana than in Botswana, where policies were grounded in a false sense of ethnic homogeneity and ultimately crystallized political power for the Tswana.

As pre-colonial ethnic groups in Ghana have been fragmented several times under British colonial rule - first at the conceptual level of the tribe and then with the institutional linkage of the tribe to the native state- there is a noticeable difference in the degree of politicization of ethnicity in Ghana as compared to Botswana. Since ethnicity and political organization in Ghana did not map neatly onto one another, no ethno-political hegemon appears to have emerged as a colonial intermediary, as with the Tswana in Botswana. Additionally, because of decentralized and ethnically crosscutting administrative policies in Ghana, inter-ethnic and inter-regional political conflict at the center remained minimal. ${ }^{198}$ Ultimately, one "prominent casualty" of British colonial administration in Ghana was the dismantling and depoliticization of pre-colonial ethnic identities. ${ }^{199}$ Depoliticization ultimately led to a much different post-independence approach to ethnic politics and minority rights in Ghana than in Botswana, where the Tswana were entrenched as ethnic and political hegemons.

\section{Post-Independence: Politicized Ethnicity as Anathema}

In 1957, Ghana became the first African nation to gain independence from colonial rule, and its emergence into nationhood-both at the discursive and institutional levels - was characterized by a lack of ethnic politics. The goal of the post-independence Ghanaian political leaders was to "create a unitary mobilizing political system in which ethnic distinctions would be eradicated in favor of a common Ghanaian nationality and a homogeneous political culture." ${ }^{200}$ Under the banner of the Convention People's Party, future-President Kwame Nkrumah claimed to represent the common man and articulated the rhetoric of both Afro-Marxism and Afronationalism. ${ }^{201}$ Although Ghana and Botswana share similarities with respect

197. LENTZ, supra note 114, at 105.

198. David R. Smock \& Audrey C. Smock, The Politics of Pluralism: A Comparative STUDY OF LEBANON AND GHANA 65 (1975).

199. See, e.g., Jean Allman, Be(com)ing Asante, Be(com)ing Akan: Thoughts on Gender, Identity, and the Colonial Encounter, in ETHNICITY IN GHANA, supra note 5, at 108 (focusing on the British colonial relationship with the Asante).

200. SMOCK \& SMOCK, supra note 198, at 6-7.

201. See BoONE, supra note 107, at 159; MACLEAN, supra note 92, at 113 (noting Nkrumah famously proclaimed "[t]he CPP is Ghana; Ghana is the CPP"). 
to their nationalist discourse, they diverge with respect to their instrumentalities. While Botswana's nationalist discourse sought to further concentrate power of the Tswana ethnic majority, Ghanaian nationalism was largely class-based and sought to unite the country. Furthermore, rather than eliminating ethnicity from Ghanaian politics, there has remained a sensitivity to ethnic pluralism in Ghana with respect to both discourse and policyundoubtedly a function of its historic depoliticization during colonialism. An important institutional difference between Botswana and Ghana was that the latter did not receive a boilerplate bill of rights from Britain. ${ }^{202}$ Instead, the Ghanaian constituent assembly required the president to make a Declaration of Fundamental Principles upon taking the oath of office; one key principle of the Declaration was respect for human rights. ${ }^{203}$ Such an institutional difference in both the nature and scope of rights suggests a more accommodationist approach to minority rights in Ghana.

As a whole, ethnic fronts have played less of a role with respect to partisan clashes in Ghana. ${ }^{204}$ At the discursive level, ethnicity has been "episodic" and "elusive" in Ghana, but in a rather surprising and counterintuitive way. ${ }^{205}$ Ethnicity is not expected to play an overt political role and is actually frowned upon as a basis for political action. For instance, Victor Owusu's pronouncement in the Parliament of the Second Republic that the Ewe ethnic group was nepotistic caused a furor because it was considered un-Ghanaian to speak in such terms. ${ }^{206}$ However, ethnicity has received "implicit support" with respect to the promotion of nation building and policies focusing on the appreciation of cultural diversity. ${ }^{207}$ This overall shift in discourse away from politicizing ethnicity while retaining it for its cultural importance is illustrated by several post-independence policies and state actions. First, the replacement of native authorities by elected local councils has further depoliticized the concept of the tribe. The concept has since evolved from being the natural foundation of Ghanaian communities to mere shorthand for groups that speak different languages and hold different cultural traditions. ${ }^{208}$ Second, the Ghanaian state has taken a particularly active role in celebrating ethnic diversity at the national level:

The full panoply of cultural festivals has been enumerated, collated and codified by central authority. It has become customary for the head of

\footnotetext{
202. PARKINSON, supra note 147 , at 132.

203. Id.

204. LENTZ, supra note 114, at 200.

205. Lentz \& Nugent, supra note 5, at 1 .

206. See SMOCK \& SMOCK, supra note 198, at 247-48 (describing one instance of the hostility and resistance towards accusations of "inward-looking tribalism").

207. Lentz \& Nugent, supra note 5, at 10.

208. Id.; LENTZ, supra note 114, at 255-56.
} 
government and the Regional Ministers to attend the most important festivals on a regular cycle. It is at the durbars that the most important speeches are delivered, from where they are relayed to the country at large by means of radio, television and the newspapers. In a sense, therefore, the Ghanaian state enacts itself at these cultural festivals. ${ }^{209}$

Lastly, Ghana has adopted a "semi-articulated policy of multiculturalism" where traditional cultural elements from different regions are incorporated into national traditions. For instance, President Jerry Rawlings has alternated between suits, kente cloths, and northern smocks on public occasions. ${ }^{210}$ Additionally, national radio and television programs have made a conscious effort to offer broadcasts in all major languages, and national institutions such as the Ghanaian Dance Ensemble incorporate songs and dances from major ethnic groups. ${ }^{211}$ Thus, the dichotomy of cultural institutionalization and political deinstitutionalization of ethnicity in Ghana neatly follows from the low degree of ethno-political cleavage developed under British colonial rule. This particular approach to ethnicity in Ghana, along with a political culture of multiculturalism, has had important implications for minority rights protections.

3. Minority Rights: Successful Integrationism

Compared to Botswana's well-documented failures to protect minority rights - illustrated by the Tswana's marginalization of the San-Ghana holds a markedly strong record of minority rights protection, influenced by the depoliticization of ethnicity during colonialism and the development of a multicultural institutional legacy in the post-independence period. Comparing Botswana and Ghana using the MAR dataset offers the first empirical glimpse into the two countries' approaches to minority rights. As of 2006 (when the MAR was last updated), the Ashanti and Ewe ethnic groups received ratings of zero with respect to the Political Discrimination variable, POLDIS; ${ }^{212}$ indicating that there is "no discrimination." 213 The

209. Lentz \& Nugent, supra note 5, at 16.

210. Id.

211. Id.

212. Minorities at Risk Project, Minorities at Risk Dataset: Ghana: Ashanti, UNIV. OF MD., COllege PARK, CTR. FOR INT'L DEV. \& CONFLiCT MGMT., http://www.mar.umd.edu/assessment.asp ?groupId=45201 [https://perma.cc/9VZJ-LHAA] (last visited Oct. 9, 2016) [hereinafter Ashanti MAR data]; Minorities at Risk Project, Minorities at Risk Dataset: Ghana: Ewe, UnIV. OF MD., COLLEGE PARK, CTR. FOR INT'L DEV. \& CONFLICT MGMT., http://www.mar.umd.edu/assessment.asp?groupId= 45202 [https://perma.cc/ 8A2A-ANCU] (last visited Oct. 9, 2016) [hereinafter Ewe MAR data]. For a discussion of the POLDIS variable, see supra text accompanying note 164 .

213. MAR Codebook, supra note 165 , at 11 . 
Ashanti and Ewe received similar ratings of zero on the Economic Discrimination variable, ECDIS; ${ }^{214}$ also evidence of "no discrimination.,"215

Undertaking a qualitative analysis of minority rights in Ghana is somewhat tricky due to a lack of data; scholars rarely write about a dog that does not bark. However, several policies illustrate of Ghana's protection of minority rights. First, the active role of the Ghanaian state in protecting and utilizing the cultural traditions of a variety of ethnic groups, both discursively and as a matter of policy, are important indicators of Ghana's multicultural political identity and tradition. ${ }^{216}$ Second, the Ghanaian state has consciously sought to integrate ethnic groups into the political process. Perhaps the most notable example was the ethnic sensitivity of President Rawlings' Ewe-led regime. ${ }^{217}$ In addition to Rawlings - an Ewe himself-the Provisional National Defense Council ("PNDC") "included two Akans, two Gas, and two northerners; moreover, the twenty-nine member cabinet was composed of seven northerners, seven Fante, three Gas, and twelve Akan members."218 It is particularly telling that an ethnic minority-led military coup appointed members of other ethnic groups, let alone the ethnic majority group (the Akan). Ultimately, this example suggests a cognizance of ethnic differences coupled with a dearth of ethno-political salience. Lastly, Ghana has a history of strong redistributional policies targeted toward ethnic groups that have been economically disadvantaged. ${ }^{219}$ For instance, President Rawlings was instrumental in implementing a structural adjustment program that effectively reversed urban-rural terms of trade in favor of rural farmers. ${ }^{220}$ Additionally, Rawlings "limited expenditures on urban hospitals to 50 percent of the national health budget in an effort to channel resources and trained personnel to less advantaged subregions." ${ }^{221} \mathrm{He}$ also "spoke of the need to establish university campuses in all of the country's subregions.",222 Accordingly, Ghana's historical legacy of ethnic depoliticization and the

214. Ashanti MAR data, supra note 212; Ewe MAR data, supra note 212. For a discussion of the ECDIS variable, see supra text accompanying note 168 .

215. MAR Codebook, supra note 165 , at 11.

216. See supra notes 200-11 and accompanying text.

217. Donald Rothchild \& Michael W. Foley, African States and the Politics of Inclusive Coalitions, in THE PRECARIOUS BALANCE, supra note 122, at 242.

218. Id.

219. RoTHCHILD, supra note 25 , at 81 .

220. See Tom Brower, Presentation at the Virginia Social Science Association Annual Conference: State Capacity Formation as Functions of Economic Crisis and International Actors: Ghana 1981-1992 15-18 (Apr. 5, 2004) (on file with author); see generally Thomas Callaghy, Lost Between State and Market: The Politics of Economic Adjustment in Ghana, Zambia, and Nigeria, in ECONOMIC CRISIS AND Policy CHOICE 257 (Joan M. Nelson ed., 1990).

221. RothCHILD, supra note 25 , at 81 .

222. Id. 
lack of an ethno-political hegemon prior to independence have fundamentally shaped Ghanaian politics which now promote multiculturalism and minority rights protection, both discursively and institutionally.

\section{REFRAMING HISTORY? MINORITY RIGHTS LOOKING FORWARD}

This Article has provided a historio-institutional approach to understanding current variations in states' protections of ethnic minority rights by focusing on the importance of colonial legacies and their enduring, path dependent effects. Rather than looking normatively at colonial governments as the "crushers of rocks" or the nefarious metaphor of Kurtz's painting, this Article focuses analytically on the variation of colonial administrations and policies with respect to how ethnicity is conceptualized, politicized, and institutionalized, and how colonial policies endure following independence and manifest themselves through starkly different levels of modern protections for ethnic minorities. Specifically, countries with a history of colonial policies that institutionalized ethnicity as a salient political cleavage and reinforced that cleavage through the utilization of a colonial intermediary are more likely to experience lower levels of minority rights protection due to the crystallization of ethnic identities and the endurance of institutional power asymmetries between ethnic groups. The Tswana ethnic majority in Botswana has followed this script in effectively marginalizing the San throughout history. However, in Ghana, ethnicity has been depoliticized due to the uneven mapping of ethnicity onto the "tribe" concept and the political institutionalization of the tribe concept into the native state. As a result, post-independence Ghana has witnessed low levels of ethnic political cleavage, recognition of the importance of ethnicity in providing cultural diversity, and a national culture of multiculturalism. Accordingly, Ghana has enjoyed a strong history of minority rights protection. Ultimately, history cannot be forgotten in understanding current human rights practices.

As a matter of policy, this Article speaks to larger questions focusing on the debate between integrationist approaches that focus on depoliticizing ethnicity through a lack of recognition and accommodationist approaches that focus on recognizing inherent ethno-cultural differences, embracing these differences, and articulating a multi-ethnic national discourse. ${ }^{223}$

Within this debate is a more specific question-how public policy, institutional design, and constitutional design can be used to accomplish the

223. See supra notes 9-14. 
aforementioned goals. A salient example of this debate is Rwanda's existing policy that bans individuals from identifying according to ethnic terms. ${ }^{224}$ This Article provides support for such policies that embrace and promote depoliticization. Historically, ethnicity in Rwanda has bred significant political cleavage, both in terms of the crystallization of previously fluid Hutu and Tutsi ethnicities by Belgian colonizers and the creation of an ethnopolitical hegemon in the Tutsis. ${ }^{225}$ Although institutions are relatively resistant to change, the 1994 genocide represents a critical juncture through which the Rwanda state can help to fundamentally change otherwise path dependent institutions. As such, Rwanda has the opportunity to depoliticize ethnicity and reform colonial-induced cleavages for future generations.

In addition to contributing to a bourgeoning research agenda focusing on the importance of historical and long-term structural conditions and their effects on human rights obligations, ${ }^{226}$ this Article itself has important implications for future research. Qualitatively, this Article's theory focusing on colonial legacies can be further explored through additional case studies. A focus on the "false twins" of Rwanda and Burundi-both colonized by Belgium and characterized by high degrees of ethno-political conflictcould contribute significantly to the theory pronounced within this Article. A comparative analysis of French colonies may be equally intriguing due to their assimilationist approaches to ethnicity and their centralized styles of colonial administration. Building on Boone's theory of uneven development, within-case analysis could be instructive to develop more nuanced theories of colonial legacies focusing on differing treatment of specific minority groups due to differences in intra-colony policy. Quantitatively, formal modeling using the MAR dataset would provide opportunities to identify and control for important historical, institutional, and structural variables that affect minority rights protections. This modeling would potentially provide more external validity to the arguments within this Article. Ultimately, understanding history is critical to understanding how states recognize

224. See Marc Lacey, A Decade after Massacres, Rwanda Outlaws Ethnicity, N.Y. TIMES (Apr. 9, 2004), http://www.nytimes.com/2004/04/09/international/africa/09RWAN.html [https://perma.cc/SYK2 $-6 \mathrm{~J} 6 \mathrm{E}]$.

225. The Hutu/Tutsi distinction has been recognized as a reference to social status rather than origin or descent. See CATHARINE NEWBURY, THE COHESION OF OPPRESSION: CLIENTSHIP AND ETHNICITY IN RWANDA, 1860-1960 12 (1988) ("It should be noted that the term 'Tuutsi' often refers not to origin (descent) but to social condition, or wealth, especially as regards cattle: whoever is a chief, or who is rich will often be referred to as Tuutsi.") (internal citation omitted); ALEXIS KAGAME, LE CODE DES Institutions PolitiQues du RWANDA PRÉCOlOnial [THE CODE OF THE POLITICAL INSTitutions of PRECOLONIAL RWANDA] 96 (1952) (“According to pastoral law, whoever possesses many heads of cattle is called Tuutsi, even if he is not of the Hamitic race.”) (author's translation); see also LEE ANN FUJI, KiLling NEIGHBORS: WeBS OF ViOLENCE IN RWANDA 56-75 (2009).

226. See generally Chilton \& Posner, supra note 7. 
minority rights that are critical within ethnically-divided societies, but often challenging to protect and enforce. 